\title{
Study of Residents' Attitude and Knowledge on Management of Solid Waste in Eastleigh, Nairobi, Kenya
}

\author{
Joseph Mbiro Muiruri, Raphael Wahome, Kiemo Karatu \\ Wangari Maathai Institute for Peace and Environmental Studies, University of Nairobi, Nairobi, Kenya \\ Email: mumbiro@yahoo.com
}

How to cite this paper: Muiruri, J.M., Wahome, R. and Karatu, K. (2020) Study of Residents' Attitude and Knowledge on Management of Solid Waste in Eastleigh, Nairobi, Kenya. Journal of Environmental Protection, 11, 779-792.

https://doi.org/10.4236/jep.2020.1110048

Received: July 25, 2020

Accepted: September 26, 2020

Published: September 29, 2020

Copyright ( 2020 by author(s) and Scientific Research Publishing Inc. This work is licensed under the Creative Commons Attribution International License (CC BY 4.0).

http://creativecommons.org/licenses/by/4.0/

\begin{abstract}
Solid waste management is no longer a non-priority issue anymore as improper waste disposal will lead to public and environmental health crisis as well as economic loss. Many nations that are developed have achieved considerable success in management of solid waste but the case is different for the developing countries as they are still grappling with issue of waste. Hence in order to bridge this gap this study calls for prioritizing and adoption of the right attitude towards proper solid waste management for the Nairobi City County. The study was conducted in order to assess residents' knowledge and attitude on solid waste management in Eastleigh South Ward, Kamukunji Sub-county in Nairobi City County, Kenya. The study evaluated and documented resident's knowledge and attitude on the types of waste generated, pre-disposal storage, management needs and associated environmental problems. The assessment employed semi-structured questionnaires with open-ended and closed questions, interviews and observations to gather information on resident's knowledge and attitude on solid waste management. The study findings indicated that residents had sufficient knowledge on solid waste management mainly on the type of waste generated at household level and environmental problems posed by poor waste management with the main source of information being from County workers. Despite the resident's knowledge, their attitude was found to be poor, more so in taking up solid waste management as part of their responsibility. About $63.6 \%$ of the respondents indicated that waste was fairly well managed with $19.5 \%$ finding it poorly managed. The findings of the study concluded that the residents had a good knowledge but poor attitude towards solid waste management. The study recommends that the County Government should organise regular clean-up exercises involving the residents as well as enforcing existing waste management rules and regulations. A sustained campaign should be mounted on the
\end{abstract}


need for a clean environment as this will help avert the feeling that waste management is a sole responsibility of the county government.

\section{Keywords}

Attitude, Knowledge, Solid Waste, Environment

\section{Introduction}

Various studies have identified a number of problems facing urban development that concern management of waste such as: lack of effective waste collection systems, neglect of basic solid waste management strategies at household level and improper disposal methods, posing a threat to ecological and public health systems. Most solid waste is generated at household level contributing greatly to solid waste impacts [1]. Although most people are aware of environmental \& health impacts of improper solid waste disposal methods, they have a negative attitude towards maintaining good environmental conditions and continue to engage in poor waste management practices [2].

Developing countries suffer greatly from inefficient solid waste management operations [3]. Provision of suitable waste management systems has been a challenge to a majority of urban authorities in developing nations, while garbage collection operations are either ineffective or do not occur at all [4]. Although more than half of all solid waste generated is recyclable, a substantial amount is dumped as garbage. Since people play a prominent role in solid waste management elements such as waste generation, source separation, storage, collection, recycling and disposal, public participation in recycling programs, would greatly reduce the amounts of waste dumped in undesignated places [5]. For successful solid waste management programs, urban authorities should not only invest in the solid waste management (SWM) infrastructure, but rather involve people by creating awareness on the value of a clean environment. To achieve sustainable SWM, in-depth understanding of the public concerns, their knowledge, behavior and their participation in waste management programs is critical. Meanwhile, dealing with SWM challenges requires local authorities to invest in cost-effective methods in order to minimize the generation of waste. Encouraging the public to recycle used materials has been found to alleviate harmful impacts of increasing amount of waste [6]. This model has worked successfully in developed countries, where $60 \%-80 \%$ and $20 \%-32 \%$ of municipal solid waste is recycled or reused, with the remaining $8 \%$ buried hygienically [3].

Understanding public health and other concerns, is requisite in planning for MSW systems and infrastructure [7]. If adopted, it will make it possible to incorporate the public in process of waste separation at the source, recycling of waste and eventual disposal through education, encouragement and persuasion [8]. For a better understanding on waste management programs in urban settings, there is need to examine residents' attitude and their participation in waste 
generation and disposal mechanisms. Such studies have been undertaken with varying findings. A study carried out by [4] among highland residents in northern Thailand findings indicated a high level of MSW management knowledge coupled with a negative attitude. Another study on knowledge, attitude and practices carried by [9] in Karan District, Mogadishu Somalia indicated that the community had a good knowledge as well as a positive attitude but their practice towards SWM was poor. Rapid increase in population in Nairobi City County has led to an increase in the waste and generated a worrying trend that calls for proper waste management. It's estimated by the year 2030, Nairobi City County could be generating $35 \%$ more waste than it does today [10]. Eastleigh is one of the areas in Nairobi City County that produces solid waste in large quantities mainly due to high influx of population and emergence of small businesses. Management of waste in Eastleigh is poor and the trend is worrying and therefore it needs to be looked into. This study aimed at assessing residents' knowledge and attitude on management of solid waste in Eastleigh South Ward, of Nairobi County, Kenya.

\section{Materials and Methods}

\subsection{Study Site}

This study was carried out in Eastleigh South Ward in Kamukunji Sub-County, Nairobi City County, Kenya. It is located on the East of Nairobi City at geographical coordinates; $1.2734^{\circ} \mathrm{S}, 36.8481^{\circ} \mathrm{E}$. The study area has a multi-ethnic population, with the Somali ethnic group vastly outnumbering others. It is one of the busy commercial areas in Nairobi County (Figure 1).

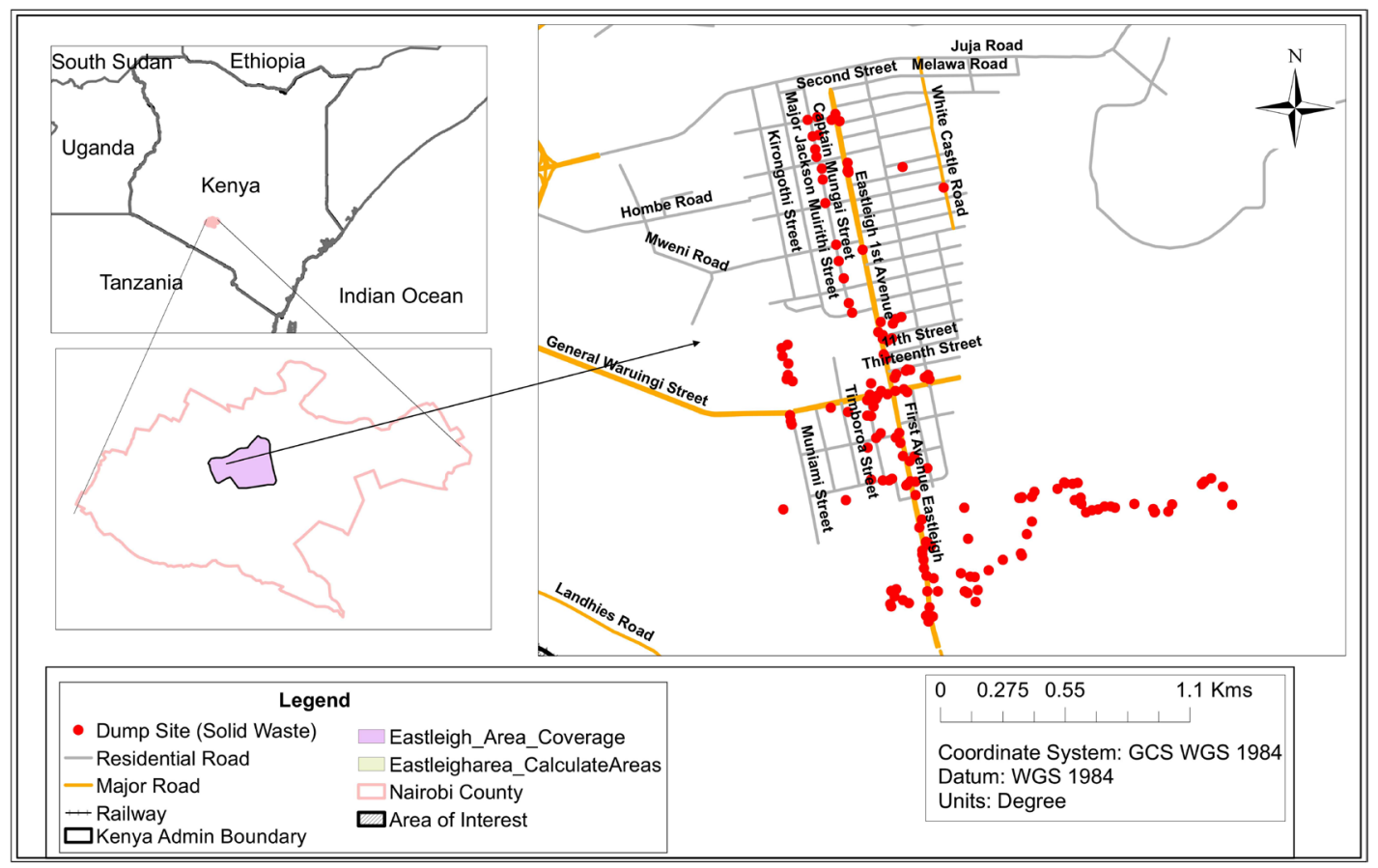

Figure 1. Map of the study area. 


\subsection{Sample Size and Sampling}

Eastleigh South Ward is within Kamukunji Sub-County, Nairobi City County. Kamukunji Sub-county covers an area of 12 square kilometres with a population of 263,462 persons [11]. The study area is mainly a business centre which has an approximate land area of 4.02431 square kilometres. According to Kenya population and housing census of 2019, the average household size is 3.1 persons. Eastleigh has a population of 89,968 persons and an estimated 29,022 households. A sample size of 188 households was derived and rounded up to the nearest hundred to give a sample size of 200 using the formula below:

$$
\begin{gathered}
n=\left(z^{2} \times p \times q \times N\right) \\
e^{2}(N-1)+\left(z^{2} \times p \times q\right)
\end{gathered}
$$

where:

$$
\begin{aligned}
& n=\text { Sample size } \text { (being determined }) \\
& N=\text { Population size }(29,022) \\
& p=\text { Sample proportion (assumed to be } 0.02, \text { if not given) } \\
& q=1-p \\
& e=0.02 \text { (since the acceptable error should be } 2 \%) \\
& Z=\text { Standard deviation at a given CI }(z=1.96 \text { at } 95 \% \mathrm{CI})
\end{aligned}
$$

\subsection{Sampling}

Sampling is a procedure, process or technique of choosing a sub-group from the population to participate in the study [12]. The apartments in the selected sections house most of the residents of the area of study. Since the target population was the households, all apartments in the three main streets in the Eastleigh South Ward were selected and three households one from each floor were randomly selected as majority of apartments had between 3 - 4 floors and also depending on residents' availability and willingness to participate in the survey.

\subsection{Data Collection}

The study used semi-structured questionnaires with open ended and closed questions in order to obtain data on knowledge and attitude of residents towards management of solid waste. Residents below 18 years of age were not involved in the study. Total sample size was divided into 3 sections namely; 1st avenue, 2nd Avenue, and 3rd street. Quantitative and qualitative approaches were used in data collection. Data on demographic information such as age, education, household size, monthly income among others was collected and questions asked on management of solid waste to assess resident's knowledge and attitude. Qualitative methods involved interviews to provide in-depth information from key informants including residents residing near the waste collection centres and private service providers. Data collected from key informants was used to add more information during the results discussion. Mixed methods approach enabled the researcher to cross check data to enable for valid and credible results 
[13]. Questionnaires were administered to the residents through an interview of sampled households. Additionally, observation schedules were used to obtain information and photos taken for documentation.

\subsection{Data Analysis}

Data collected through questionnaires and interview schedules was analysed using Statistical Package for Social Sciences (SPSS) version 21.0. Descriptive statistics were obtained where parameters such as frequencies and percentages were calculated to depict knowledge, attitudes, composition, solid waste level, waste storage and demographic characteristics. The relationship between household demographic characteristics and solid waste management knowledge and attitude was assessed by cross tabulation and chi-square analysis at a significance level of less than 5\%. Qualitative data was used to add more information during results discussion.

\section{Results and Discussion}

\subsection{Sample Distribution}

Demographic characteristics of individuals; age, marital status, education level, monthly income and size of family have been found to be a vital component when evaluating peoples' knowledge, attitude and practice (KAP) [14]. Among the 200 questionnaires distributed, 118 residents (59\%) of the target respondents consented to answer the questions which were within what [15] prescribed as a significant response rate for statistical analysis and established it at minimum value of $50 \%$. More data was sourced from key informants in the study area. The demographic characteristics of the respondents are presented in Table 1. Majority were aged between 18 - 44 years (85.5\%), 55.1\% of whom were married. Majority of respondents (55.9\%) had secondary education level. Most respondents'

Table 1. Characteristics of residents studied.

\begin{tabular}{|c|c|c|c|c|c|}
\hline Demographic Characteristics & & & Male & Female & Total \\
\hline \multirow{12}{*}{ Age Group } & \multirow{2}{*}{$18-24$ Years } & $\mathrm{N}$ & 17 & 15 & 32 \\
\hline & & $\%$ & $14.40 \%$ & $12.70 \%$ & $27.10 \%$ \\
\hline & \multirow{2}{*}{25 - 34 Years } & $\mathrm{N}$ & 26 & 23 & 49 \\
\hline & & $\%$ & $22.00 \%$ & $19.50 \%$ & $41.50 \%$ \\
\hline & \multirow{2}{*}{$35-44$ Years } & $\mathrm{N}$ & 15 & 5 & 20 \\
\hline & & $\%$ & $12.70 \%$ & $4.20 \%$ & $16.90 \%$ \\
\hline & \multirow{2}{*}{45 - 54 Years } & $\mathrm{N}$ & 9 & 6 & 15 \\
\hline & & $\%$ & $7.60 \%$ & $5.10 \%$ & $12.70 \%$ \\
\hline & \multirow{2}{*}{ Over 55 Years } & $\mathrm{N}$ & 1 & 1 & 2 \\
\hline & & $\%$ & $0.80 \%$ & $0.80 \%$ & $1.70 \%$ \\
\hline & \multirow{2}{*}{ Total } & $\mathrm{N}$ & 68 & 50 & 118 \\
\hline & & $\%$ & $57.60 \%$ & $42.40 \%$ & $100.00 \%$ \\
\hline
\end{tabular}




\section{Continued}

\begin{tabular}{|c|c|c|c|c|c|}
\hline & \multirow{2}{*}{ Single } & $\mathrm{N}$ & 29 & 16 & 45 \\
\hline & & $\%$ & $24.60 \%$ & $13.60 \%$ & $38.10 \%$ \\
\hline & \multirow{2}{*}{ Married } & $\mathrm{N}$ & 36 & 29 & 65 \\
\hline & & $\%$ & $30.50 \%$ & $24.60 \%$ & $55.10 \%$ \\
\hline \multirow{10}{*}{ Marital Status } & \multirow{2}{*}{ Separated } & $\mathrm{N}$ & 1 & 3 & 4 \\
\hline & & $\%$ & $0.80 \%$ & $2.50 \%$ & $3.40 \%$ \\
\hline & \multirow{2}{*}{ Widowed } & $\mathrm{N}$ & 2 & 2 & 4 \\
\hline & & $\%$ & $1.70 \%$ & $1.70 \%$ & $3.40 \%$ \\
\hline & \multirow{2}{*}{ Total } & $\mathrm{N}$ & 68 & 50 & 118 \\
\hline & & $\%$ & $57.60 \%$ & $42.40 \%$ & $100.00 \%$ \\
\hline & \multirow{2}{*}{ None } & $\mathrm{N}$ & 1 & 0 & 1 \\
\hline & & $\%$ & $0.80 \%$ & $0.00 \%$ & $0.80 \%$ \\
\hline & \multirow{2}{*}{ Primary } & $\mathrm{N}$ & 5 & 4 & 9 \\
\hline & & $\%$ & $4.20 \%$ & $3.40 \%$ & $7.60 \%$ \\
\hline \multirow{6}{*}{ Education Level } & \multirow{2}{*}{ Secondary } & $\mathrm{N}$ & 38 & 28 & 66 \\
\hline & & $\%$ & $32.20 \%$ & $23.70 \%$ & $55.90 \%$ \\
\hline & \multirow{2}{*}{ College } & $\mathrm{N}$ & 24 & 18 & 42 \\
\hline & & $\%$ & $20.30 \%$ & $15.30 \%$ & $35.60 \%$ \\
\hline & \multirow{2}{*}{ Total } & $\mathrm{N}$ & 68 & 50 & 118 \\
\hline & & $\%$ & $57.60 \%$ & $42.40 \%$ & $100.00 \%$ \\
\hline \multirow{10}{*}{ Monthly Income } & \multirow{2}{*}{$<$ Ksh. 10,000} & $\mathrm{~N}$ & 14 & 5 & 19 \\
\hline & & $\%$ & $11.90 \%$ & $4.20 \%$ & $16.10 \%$ \\
\hline & \multirow{2}{*}{ Ksh. $10,000-20,000$} & $\mathrm{~N}$ & 28 & 23 & 51 \\
\hline & & $\%$ & $23.70 \%$ & $19.50 \%$ & $43.20 \%$ \\
\hline & \multirow{2}{*}{ Ksh. $20,000-50,000$} & $\mathrm{~N}$ & 21 & 21 & 42 \\
\hline & & $\%$ & $17.80 \%$ & $17.80 \%$ & $35.60 \%$ \\
\hline & \multirow{2}{*}{ Ksh. $50,000-100,000$} & $\mathrm{~N}$ & 5 & 1 & 6 \\
\hline & & $\%$ & $4.20 \%$ & $0.80 \%$ & $5.10 \%$ \\
\hline & \multirow{2}{*}{ Total } & $\mathrm{N}$ & 68 & 50 & 118 \\
\hline & & $\%$ & $57.60 \%$ & $42.40 \%$ & $100.00 \%$ \\
\hline
\end{tabular}

monthly earnings ranged between Ksh. 10,000 - 20,000 which accounted for 43.2\% (Table 1).

In the study, variables of age, education, and monthly income were not identified as influencing factors to residents' attitude. Despite most of the residents having secondary education and above, their attitude was found to be negative towards good solid waste management practices. Residents of ages between 18 44 years were found to be the majority, an age at which they are expected to have interacted with the environment and gained enough experience to manage waste 
yet they had poor attitude. On monthly income, majority earned between Ksh. $10,000-20,000$ but they were reluctant to pay for waste management services to the private waste collectors.

\subsection{Residents' Knowledge on Solid Waste Management}

According to [16], knowledge is all about gaining a variety of experiences and acquiring a basic understanding of the environment and its associated problems. Knowledge is familiarity with someone or something which can include facts, information, description or skills acquired through experience or education. Residents' knowledge on solid waste management was accessed through various parameters.

\subsubsection{Types of Generated Waste}

The research assessed the residents' knowledge on the type of waste generated in their households. Respondents were asked to state the nature of waste they generate. According to the responses given the respondents showed good knowledge on the type of waste generated in their households which comprised both organic (Bio-degradable) and inorganic waste (Non-biodegradable). Most of the organic waste generated was from food remains, rotten fruits and vegetable peels which accounts for $43.0 \%$. Additionally, old clothing and human waste accounted for $12.7 \%$ and $3.4 \%$ respectively (Figure 2).

Inorganic waste was mainly generated from various plastics (40.6\%), empty bottles (32.3\%), broken and obsolete cutlery (plates, spoons and cups) (18.9\%) with $4.2 \%$ of the waste generated from glass and metal while $2.5 \%$ was from broken and old furniture (Figure 3).

The findings of the study indicated that due to poor methods for waste collection, storage, separation and disposal waste ended up in undesignated areas. Providing suitable management systems of waste in residential areas would reduce solid materials production and create effective systems in the city [17]. Identification of types of solid waste generated within the business zone is vital

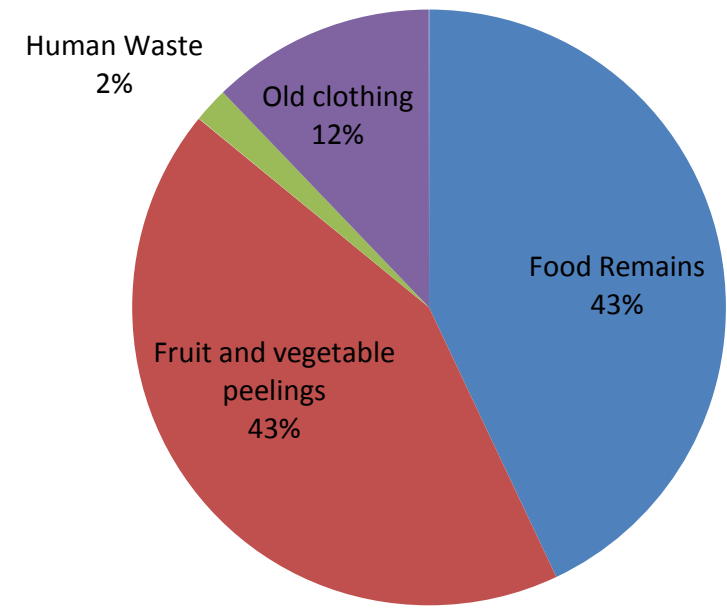

Figure 2. Organic waste (bio-degradable). 


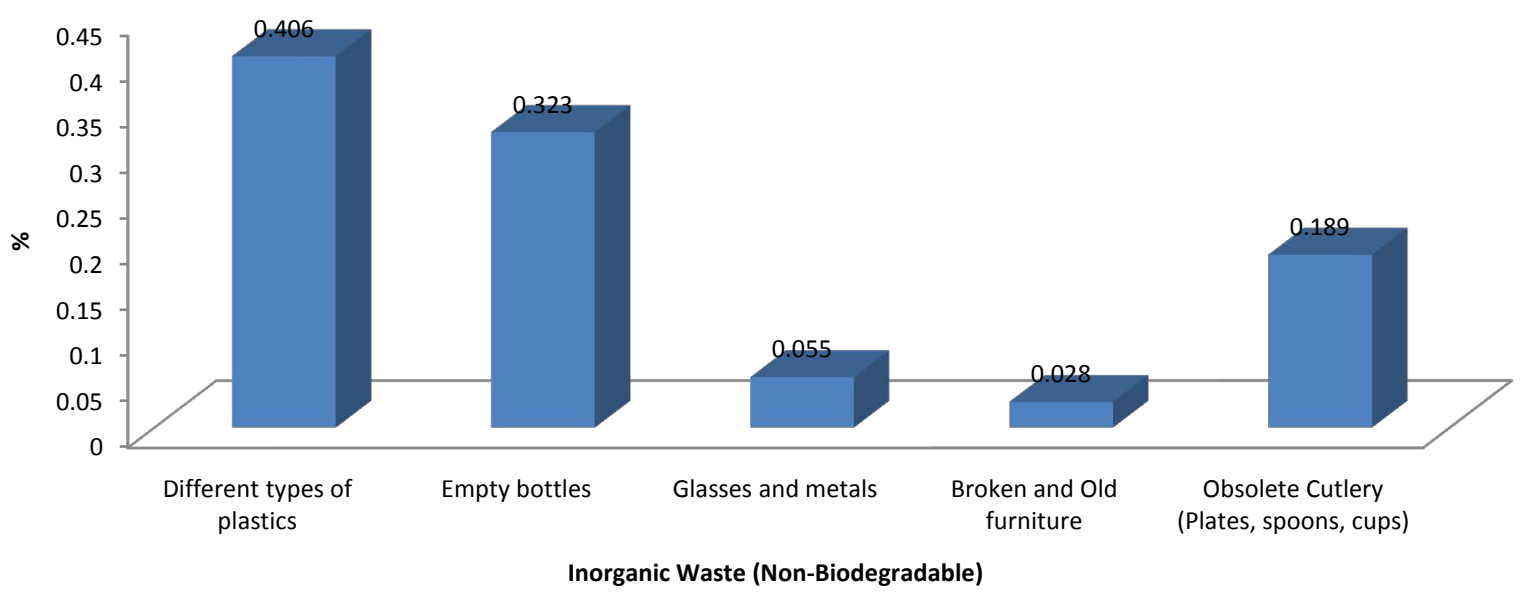

Figure 3. Inorganic waste (non-biodegradable).

to help in determining viable management plans and programs to involve the public in. To reduce the use of plastics, strong campaigns against single use are needed to avoid high production of plastic materials such as bottles and food containers.

\subsubsection{Waste Sorting and Separation}

The sorting of waste before disposal is beneficial since this would help separate recyclable material from un-recyclables. Residents were asked to indicate whether they sorted waste before disposal, though majority (65.7\%) of the respondents claimed to sort waste, however, from observations done it was found out that waste was unsorted before disposal. According to key informants, people did not sort solid waste generated while those who sorted it did the sorting at the collection centres and sold the sorted waste to buyers. The study established that residents had little or no knowledge on sorting and that explains why most of the waste was left unsorted. Interestingly, waste paper collectors are the ones who sort and separate waste at the illegal dump sites for sale to recycling firms, residents are also not compelled to sort waste. Failure to sort may be attributed to lack of residents' interest in waste disposal as it did not have a pecuniary interest to them. Capacity building in sorting of pre-disposal waste can therefore be beneficial and facilitate reusing and recycling of waste.

\subsubsection{Solid Waste Service Providers}

The researcher assessed residents' knowledge on who the solid waste service providers were in their area. About $53.4 \%$ of the household respondents indicated private collectors were mainly responsible for collection of waste at household level. Another $30.5 \%$ of the residents indicated Nairobi City County Government was responsible while $7.6 \%$ indicated collectors were unknown people to the residents. However, $3.4 \%$ of the respondents showed no knowledge on who collects waste in their area (Table 2). According to key informants, waste from the households was put in a central collection point in sacks, plastic containers, metallic bins as well as in County Skips awaiting collection by service 
Table 2. Waste collection.

\begin{tabular}{cccc}
\hline Question & Waste collection & Frequency & Percent \\
\hline & Private collector & 63 & 53.4 \\
& Nairobi county council & 36 & 30.5 \\
Who collects waste in your area? & Unknown people & 9 & 7.6 \\
& Self & 6 & 5.1 \\
& Nobody collects the waste at all & 4 & 3.4 \\
& Total & $\mathbf{1 1 8}$ & $\mathbf{1 0 0 . 0}$ \\
\hline
\end{tabular}

providers who included private collectors and Nairobi City County to the designated dump site in Dandora. However, collection equipment(s) are not adequate leading to solid waste pile-up. Nairobi City County Government should provide adequate equipment and regularize collection and disposal to avoid accumulation of uncollected waste.

\subsubsection{Sources of Information on Waste Management}

Information to the public on proper solid waste management is critical. The County Government and other environmental agencies should provide this information to the residents' in order to create greater awareness. Residents' were asked to mention sources of public information on waste management in the area. The study results indicated that residents were well informed on waste management information sources with $81.0 \%$ indicating information was sourced from county workers; another $4.8 \%$ indicated media as the source of information. A small number of respondents (2.9\%) cited community volunteers as the source of information, $11.0 \%$ of the respondents had no idea on how waste was managed, an indicator of poor knowledge on proper waste management (Figure 4). Although most respondents indicated information on solid waste management was available, observation revealed that it was not reflected in their practices. The County Government and other environmental agencies need to have clear communication channels so that crucial information can reach residents' in order to inform attitude.

\subsubsection{Environmental Problems}

An unhealthy environment breeds illnesses and affects livelihoods. Residents' knowledge on environmental problems associated with poor waste management in Eastleigh was accessed. Respondents' showed good knowledge on the impact of poor waste management which included blocked sewage drainage system (26.1\%), air pollution and health issues at (23.9\%), land pollution (21.7\%), while water pollution was least at $4.4 \%$ (Table 3). Report from key informants showed the main health and environmental impacts of poor solid waste management was blockages in sewer lines which consequently lead to water borne diseases that is a risk to human health. The findings of the study indicated residents had knowledge and were aware of the dangers of an unhealthy environment. Enhancing 


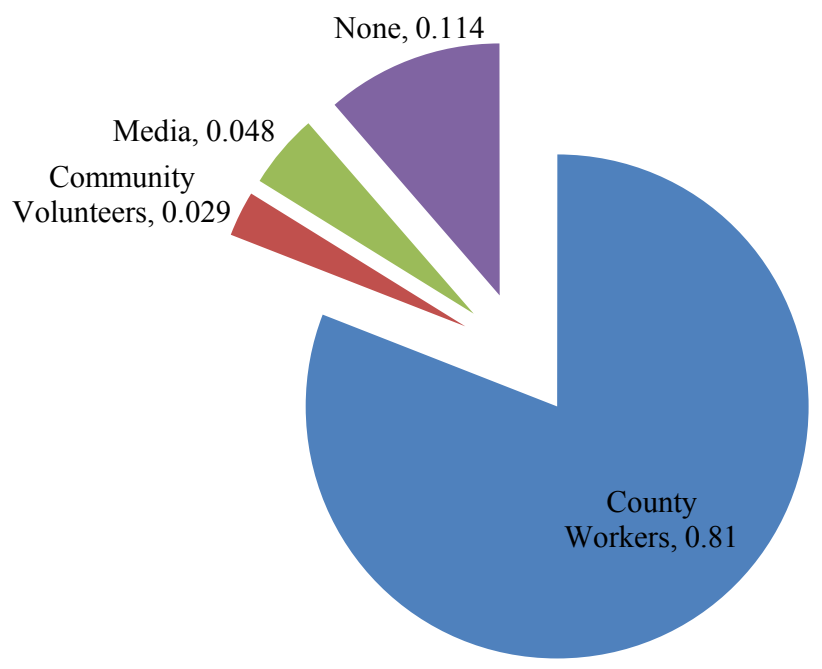

Figure 4. Sources of public information on waste management in the area.

Table 3. Environmental problems associated with poor solid waste management.

\begin{tabular}{ccc}
\hline Environmental Problems & Frequency & Percent \\
\hline Health issues & 43 & 23.9 \\
Air pollution & 43 & 23.9 \\
Land pollution & 39 & 21.7 \\
Water pollution & 8 & 4.4 \\
Blockage of sewage drainage & 47 & 26.1 \\
Total & $\mathbf{1 8 0}$ & $\mathbf{1 0 0 . 0}$ \\
\hline
\end{tabular}

resident's environmental awareness would be the most effective method to improve solid waste issues [18].

\subsection{Residents Attitude on Solid Waste Management}

[19], defines attitude as acquisition of values and feelings of concern for something. If positive values towards solid waste management were inculcated in residents they would get more involved in conserving the environment. According to [20], attitude is a state of alertness of mind which through experience is organized and directs the individual's behaviour towards something. Attitude has a great influence on how an individual thinks towards a thing or a situation. It drives an individual's reaction since it tags along with its deep feeling and emotion. This explains why people react to the same situation differently. While some may value a clean environment others may not, and not because they do not know the value but they simply don't care. In the study residents attitude was derived from their behaviour towards solid waste management.

\subsubsection{Waste Collection and Disposal}

Residents were asked if they bother to know where waste is taken for disposal after collection. Majority of the residents (63.6\%) indicated they have never bo- 
thered which is an indicator of their negative attitude since they did not find it their responsibility to collect and dispose waste. Nairobi City County Government should instil a sense of shared responsibility in the residents through capacity building.

According to the study findings about $91 \%$ of the residents have secondary education and above a clear indication knowledge is abundant. However, despite their knowledge they discard waste indiscriminately. This is evidenced by the amount of waste observed discarded by the roadside and in the drainage systems. This behaviour appears to give credence to [21] argument that the reason for continued increase of waste in urban centres is occasioned by some residents care free attitude who despite knowing what should be done do not care at all. The County Government should provide adequate waste collection facilities while at the same time enforcing existing rules and regulations on waste management to curb the vice.

\subsubsection{Participation in Solid Waste Management}

Residents were asked if they have ever participated in environmental clean-up activities. About $48 \%$ of the residents indicated they have never participated in any (Figure 5). This is an indication that unclean environment does not bother them further depicting their negative attitude [21] attributes continued growth of the amount of waste in urban areas to ignorance of some residents towards the impact of uncontrolled dumping and they don't care attitude displayed by some resident. The County Government should involve the residents in anti-littering campaigns while at the same time organising programmed clean-up exercises.

Residents were asked if they ever discuss waste management issue with the concerned authority, $43 \%$ of the residents indicated that they do not see the need to discuss poor waste management issue with the relevant authorities although they also indicated that heaps of waste in the environment was annoying. This scenario supports the proposition that people do not appraise or discuss with their neighbours on the need to change their attitude towards waste management [22]. They argue if a person is seen placing waste in undesignated area, it is imperative to inform the individual instead of displaying annoyance to such a

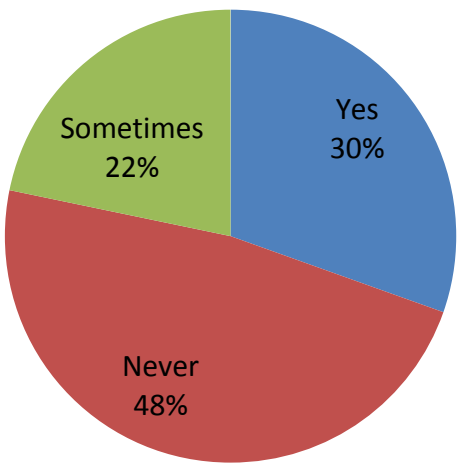

Figure 5. Participation in solid waste management. 
situation. The County Government should ensure that every resident is held accountable for their behaviour by imposing fines on the offenders as stipulated in the rules and regulations.

\subsubsection{Solid Waste Management}

Residents were asked to indicate whether everybody had a responsibility in waste management. Majority of the residents (82.6\%) thought that not everybody had a responsibility. This shows they were not willing to contribute towards better solid waste disposal in their locality an indicator of a negative attitude. Nairobi City County should sensitize residents on the need for a clean environment and involve them more in waste management by nominating some residents in policy implementation committees. From residents behaviour the study deduced that the residents had a negative attitude. To address the solid waste management challenges in Eastleigh, residents' attitude ought to be changed positively.

\section{Conclusion}

The findings of this study show that the residents of Eastleigh South Ward have good knowledge on many aspects related to solid waste management. However, this knowledge is in total contrast with their attitude which the study found to be negative. The negative attitude has impacted negatively on environmental and health situation in the study area. The County Government was found responsible for the apathy in the residents owing to its laxity in collection and disposal of waste including failure to provide waste storage equipment. Since residents have knowledge of solid waste management, focus should be geared towards changing their attitude on the need to maintain a clean environment.

\section{Recommendation}

The study recommends that Nairobi City County Government should regularly organise programmed clean-up exercises and involve the residents. Capacity building programs on the value of a clean environment should be organised through campaigns in schools, mosques, churches and in public gatherings. More information on sorting should be availed to the residents to make it possible to separate the recyclable from the unrecyclable materials. The County Government should regularize waste collection while at the same time enforcing the existing waste management rules and regulations. Thus, an integrated solid waste management program should be adopted which involves the entire chain from household to the collection points through to the designated dump sites.

\section{Acknowledgements}

I'm grateful to my supervisors Prof. Wahome and Dr. Kiemo for their devotion and guidance, Wangari Maathai Institute staff for their unwavering support. I would also like to thank all my respondents in Eastleigh estate for their contributions. 


\section{Conflicts of Interest}

The authors declare no conflicts of interest regarding the publication of this paper.

\section{References}

[1] Karak, T., Bhagat, R.M. and Bhattacharyya, P. (2012) Municipal Solid Waste Generation, Composition, and Management: The World Scenario. Critical Reviews in Environmental Science and Technology, 42, 1509-1630. https://doi.org/10.1080/10643389.2011.569871

[2] Licy, C.D., Vivek, R., Saritha, K., Anies, T.K. and Josphina, C.T. (2013) Awareness, Attitude and Practice of School Students towards Household Waste Management. Journal of Environment, 2, 147-150.

[3] Jamshidi, A., Taghizadeh, F. and Ata, D. (2011) Sustainable Municipal Solid Waste Management (Case Study: Sarab County, Iran). Annals of Environmental Science, 5, 55-59.

[4] Laor, P., Suma, Y., Keawdounglek, V., Hongtong, A., Apidechkul, T. and Pasukphun, N. (2018) Knowledge, Attitude and Practice of Municipal Solid Waste Management among Highland Residents in Northern Thailand. Journal of Health Research, 32, 123-131. https://doi.org/10.1108/JHR-01-2018-013

[5] Nasrabadi, T., Hoveidi, H., Bidhendi, G.N., Yavari, A.R. and Mohammadnejad, S. (2008) Evaluating Citizen Attitudes and Participation in Solid Waste Management in Tehran, Iran. Journal of Environmental Health, 71, 30-33.

[6] Ehrampoush, M.H. and Moghadam, M.B. (2005) Survey of Knowledge, Attitude and Practice of Yazd University of Medical Sciences Students about Solid Wastes Disposal and Recycling. Journal of Environmental Health Science \& Engineering, 2, 26-30.

[7] Chung, S.S. and Lo, C.W. (2008) Local Waste Management Constraints and Waste Administrators in China. Waste Management, 28, 272-281.

https://doi.org/10.1016/j.wasman.2006.11.013

[8] De Feo, G. and De Gisi, S. (2010) Public Opinion and Awareness towards MSW and Separate Collection Programmes: A Sociological Procedure for Selecting Areas and Citizens with a Low Level of Knowledge. Waste Management, 30, 958-976.

https://doi.org/10.1016/j.wasman.2010.02.019

[9] Desa, A., Ba'yah AbdKadir, N. and Yusooff, F. (2010) A Study on the Knowledge, Attitudes, Awareness Status and Behaviour Concerning Solid Waste Management School of Psychology and Human Development, UniversitiKebangsaan Malaysia, 43600 UKM Bangi, Malaysia.

[10] Kasozi, A. and von Blottnitz, H. (2010) Solid Waste Management in Nairobi: A Situation Analysis Technical Document Accompanying the Integrated Solid Waste Management Plan. University of Cape Town, Cape Town, 59.

[11] Kenya National Bureau of Statistics (2019) 2019 Kenya Population and Housing Census Volume I: Population by County and Sub-County.

[12] Ogula, P.A. (2005) Research Methods.

[13] Bryman, A., Becker, S. and Sempik, J. (2008) Quality Criteria for Quantitative, Qualitative and Mixed Methods Research: A View from Social Policy. International Journal of Social Research Methodology, 11, 261-276.

https://doi.org/10.1080/13645570701401644 
[14] Castagna, A., Casagranda, M., Zeni, A., Girelli, E., Rada, E.C., Ragazzi, M. and Apostol, T. (2013) 3R'S from Citizens Point of View and Their Proposal from a Case-Study. UPB Scientific Bulletin, 75, 253-264.

[15] Sekaran, U. (2003) Research Methods for Business: A Skill-Building Approach. John Willey and Son, New York.

[16] Schratz, M. (2016) Austria: Overcoming a Bureaucratic Heritage as a Trigger for Research on Leadership in Austria. In: Anlesing, H., Day, C. and Johansson, O., Eds., A Decade of Research on School Principals. Cases from 24 Countries, Springer, Dordrecht, 307-329. https://doi.org/10.1007/978-3-319-23027-6_15

[17] Grey, C.N., Nieuwenhuijsen, M.J., Golding, J. and ALSPAC Team (2005) The Use and Disposal of Household Pesticides. Environmental Research, 97, 109-115. https://doi.org/10.1016/j.envres.2004.07.008

[18] Song, Q., Wang, Z. and Li, J. (2016) Exploring Residents' Attitudes and Willingness to Pay for Solid Waste Management in Macau. Environmental Science and Pollution Research, 23, 16456-16462. https://doi.org/10.1007/s11356-016-6590-8

[19] Momoh, J.J. and Oladebeye, D.H. (2010) Assessment of Awareness of Attitude and Willingness of People to Participate in Household Solid Waste Recycling Programme in Abo-Eketi, Nigeria. Journal of Applied Science in Environmental Sanitation, 14, 1-12.

[20] United Nations Human Settlements Programme (2006) The State of the World's Cities 2006/2007: The Millennium Development Goals and Urban Sustainability: 30 Years of Shaping the Habitat Agenda (Vol. 3). Routledge, New York.

[21] Chekole, Z.F. (2006) Controlling the Informal Sector: Solid Waste Collection and the Addis Ababa City Administration, 2003-2005. Masters, Norwegian University of Science and Technology, Trondheim.

[22] Alem, S. (2007) New Partners for Local Government in Service Delivery: Solid Waste Management in Addis Ababa. Master of Science Thesis in Urban Management, University of Technology, Berlin. 